\title{
Notes
}

\section{The Standstill Agreement: A Case of Illegal Vote Selling and a Breach of Fiduciary Duty}

A standstill agreement between Martin Marietta and Allied Corporation $^{1}$ was a vital component in the resolution of the recent and much publicized Martin Marietta-Bendix Corporation takeover battle. Although such standstill agreements are designed to achieve some valid corporate purposes, ${ }^{2}$ the voting restrictions ${ }^{3}$ inherent in them call their legality into question. This Note argues that courts should invalidate this type of agreement as a case of illegal shareholder vote selling or as a breach of management's fiduciary duty to its shareholders.

The Note proposes several solutions to this new problem. The adoption of either Proposal One, making stock which is subject to a standstill agreement nonvoting, or Proposal Two, requiring proportional voting of all shares subject to a standstill agreement, would ensure that these agreements are used only to achieve proper corporate purposes. Both Proposal One and Proposal Two would eliminate the improper use of standstill

1. The complete text of the Martin Marietta-Allied standstill agreement can be found in Lock-Up and Siandstill Agreements, 412 P.L.I. 497-530 (1983) [hereinafter cited as Martin Marietta-Allied Agreement].

2. The main purpose of most standstill agreements is to define and govern, with legal certainty, a cooperative relationship between the management of a corporation and a substantial shareholder.

3. The major voting restriction in most standstill agreements is that all shares governed by the agreement must be voted as the management of the corporation dictates in any election of the corporation's board of directors. See, e.g., Martin Marietta-Allied Agreement, supra note 1, at 507; Norcen Energy Resources Limited-Hanna Mining Company Agreement 11 (July 7, 1982) (Exhibit 5 to Schedule 13D (amend. 3), filed with the Securities and Exchange Commission (SEC) by Norcen Energy Resources Limited on July 10,1982) [hereinafter cited as Norcen-Hanna Agreement]; Scott Paper Company-Brascan Limited Agreement 10 (Mar. 21, 1981) (Exhibit A to Schedule 13D (amend. 2), filed with the SEC by Brascan Limited on Mar. 27, 1981) (hereinafter cited as Scott Paper-Brascan Agreement]; Seagram-DuPont standstill agreement, Lock-Up and Standstill Agreements, 412 P.L.I. 531, 535 (1983) [hereinafter cited as Seagram-DuPont Agreement]; Whittaker Corporation-Smith International Inc. Agreement 4 (Jan. 20, 1983) (Exhibit 1 to Schedule 13D (amend. 3), filed with the SEC by Whittaker Corp. on Jan. 27, 1983) [hereinafter cited as Whittaker-Smith Agreement]. 
agreements as a "shark repellent" technique" but would still allow such agreements as a cost efficient and nondestructive method of dealing with a major shareholder. Proposal Three, reversing the presumption of the business judgment rule if a standstill agreement contains severe voting restrictions, would increase the likelihood of a successful shareholder suit challenging such an agreement, thereby ensuring closer and more effective monitoring of standstill agreements.

\section{BACKGROUND}

A standstill agreement is a long-term contract in which an entity with substantial holdings ("the contracting shareholder") generally agrees that it will not buy any more of the corporation's stock without management's prior written approval, ${ }^{6}$ will not sell or transfer its stock $^{7}$ without management's written permission, ${ }^{8}$ and will vote all its stock as management

4. A shark repellent is any tactic used to make all future hostile takeover attempts more difficult, thereby convincing a potential offeror not even to attempt an attack on this target but to seek a less well-prepared target. Such tactics save the target the substantial costs associated with takeover battles and, more importantly, eliminate the risk that all defensive measures will fail and the hostile offer will prove successful. Gilson, The Case Against Shark Repellent Amendments: Structural Limitations on the Enabling Concept, 34 StAN. L. Rev. 775, 776-77 (1982).

5. See Martin Marietta-Allied Agreement, supra note 1, at 517 (10-year term); Seagram-DuPont Agreement, supra note 3, at 531 (same); Harnischfeger Corporation-Kobe Steel Ltd. Ágreement 21 (May 7, 1981) (Exhibit A to Schedule 13D, filed with the SEC by Kobe Steel Ltd. on May 14, 1981) (approximately 91/2-year term) [hereinafter cited as Harnischfeger-Kobe Agreement]; Norcen-Hanna Agreement, supra note 3, at 2 (8-year term).

6. Typically, the contracting shareholder's stock limitation ranges from $20 \%$ to $40 \%$ of the corporation's outstanding common stock. See Martin Marietta-Allied Agreement, supra note 1, at 509-11 (39\% limitation); Seagram-DuPont Agreement, supra note 3, at 533 (25\% limitation); City Investing Company-NVF Company Letter Agreement 1 (Aug. 1, 1980) (Exhibit 2 to Schedule 13D (amend. 8), filed with the SEC by Sharon Steel Corporation on Aug. 18, 1980) (21\% limitation) [hereinafter cited as City Investing-NVF Agreement]; Scott Paper-Brascan Agreement, supra note 3, at 7 (20.5\% limitation through Mar. 31, 1982, 25\% limitation through Dec. 31, 1985); Norcen-Hanna Agreement, supra note 3 , at 7 (20\% limitation).

7. Transfers which assure wide distribution of the stock and by their very nature do not raise the specter of a control contest are often permitted. These could include: (1) transfers which, as to a single disposition, do not exceed a specified small percentage of the corporation's outstanding voting securities; (2) transfers made pursuant to an underwritten public distribution registered under the Securities Act of 1933, 15 U.S.C. $\$ \S 77 a-77 a a$ (1982) (the "1933 Act"), in which the contracting shareholder is obligated to use its best efforts to distribute the stock as widely as possible and to prevent any single buyer from acquiring more than a specified small percentage of the corporation's voting securities then outstanding; and (3) transfers made in a transaction or series of deals exempt from registration under the 1933 Act by reason of SEC Rule 144, 17 C.F.R. $\S 230.144$ (1983), which permits resale of restricted securities without registration, provided that requirements relating to public information, holding period, limitation on amount sold, and limitation on manner of sale are met. Bartlett \& Andrews, The Standstill Agreement: Legal and Business Considerations Underlying a Corporate Peace Treaty, 62 B.U.L. REv. 143, 158-59 (1982); Nathan, Corporate Stock Repurchases and Stock Issuances in the Context of Unsolicited Takeover Bids, 319 P.L.I. 289, 359 (1979).

8. Although an absolute prohibition on transfer would probably constitute an unreasonable restraint on alienation, see Tracey v. Franklin, 31 Del. Ch. 477, 484-85, 67 A.2d 56, 59-60 (1949); Greene v. E.H. Rollins \& Sons, Inc., 22 Del. Ch. 394, 403-04, 2 A.2d 249, 253-54 (1938); Allen v. Biltmore Tissue Corp., 2 N.Y.2d 534, 542, 141 N.E.2d 812, 816, 161 N.Y.S.2d 418, 423 (1957); H. Henn \& J. Alexander, Laws of Corporations $\$ 281$, at 758 (3d ed. 1983), Delaware law 
directs in any election of the corporation's board of directors. ${ }^{9}$ In exchange, management typically agrees that it will give the contracting shareholder representation on the corporation's board of directors, ${ }^{10}$ will not oppose the shareholder's purchase of stock up to a specified limit, and will allow the shareholder certain securities registration rights. ${ }^{11}$ Standstill agreements have only recently developed as an important instrument in corporate transactions: Most of the significant standstill agreements have been executed within the last three years. ${ }^{12}$

Standstill agreements most frequently arise when one corporation acquires ${ }^{13}$ a significant portion of a second corporation's stock and the tar-

explicitly provides that a restriction on the transfer of securities is permitted if it "[r]equires the corporation . . . to consent to any proposed transfer of the restricted securities." DEL. CODE ANN. tit. $8, \S 202(c)(3)(1974)$.

9. As a means of protecting its substantial investment, the contracting shareholder is often given the right to vote as it wishes on significant events out of the ordinary course of the corporation's business. These events are typically defined as: a charter or by-law amendment; an acquisition or disposition of assets by way of merger, consolidation or otherwise; a change in capitalization; or a liquidation of the corporation. See, e.g., Martin Marietta-Allied Agreement, supra note 1, at 508; Seagram-DuPont Agreement, supra note 3, at 536; Whittaker-Smith Agreement, supra note 3, at 5.

10. See Martin Marietta-Allied Agreement, suprn note 1, at 518 (shareholder may designate two directors); Norcen-Hanna Agreement, supra note 3, at 22-23 (shareholder may designate three directors, and at least one must be on the audit committee and one on the executive committee); Scott Paper-Brascan Agreement, supra note 3, at 9-10 (shareholder may designate up to four directors); Seagram-DuPont Agreement, supra note 3, at 541 (shareholder may designate two directors); Whittaker-Smith Agreement, supra note 3, at 12 (shareholder may designate one director).

11. Management grants the contracting shareholder "demand securities registration rights," which require management, at the request of the shareholder, to use its best efforts to register under the 1933 Act any proposed public offering of the shareholder's holdings. The registration clause facilitates the contracting shareholder's access to the public market. The registration-rights provisions of a standstill agreement can cover a wide variety of issues: which SEC form for registration may be used by management, and whether the contracting shareholder can specify the form for registration; the number of registration statements the shareholder can require management to file; the minimum and maximum amounts of shares as to which the shareholder may require registration; allocation of costs associated with registration; the right, if any, of management to refuse to register the shares if the registration would materially interfere with acquisitions, reorganizations, or other similar transactions; the extension of registration rights under the appropriate Blue Sky laws; any indemnification rights or limitations arising out of any registration; rights as to participation in the meetings for preparation of the registration statement; the time during which the registration must be kept effective and updated, and a current prospectus provided; the shareholder's right to request (or require) a "shelf" registration; and the right of management, upon advice of its managing underwriter, to refuse to include the shareholder's securities in a "piggy-back" registration. Bartlett \& Andrews, supra note 7, at 172-73; Nathan, supra note 7, at 363-64.

12. See Whittaker-Smith Agreement, supra note 3, at 1 (executed on Jan. 20, 1983); Martin Marietta-Allied Agreement, supra note 1, at 497 (executed on Sept. 24, 1982); Norcen-Hanna Agreement, supra note 3, at 1 (executed on July 7, 1982); Seagram-DuPont Agreement, supra note 3, at 531 (executed on Oct. 2, 1981); Harnischfeger-Kobe Agreement, supra note 5, at 1 (executed on May 7, 1981); Scott Paper-Brascan Agreement, supra note 3, at 1 (executed on Mar. 21, 1981).

13. The stock can be acquired by various methods including open market purchases, privately negotiated purchases, or the purchase of a block of authorized but unissued shares directly from a corporation that is a takeover target or perceives itself to be a potential takeover target in the near future. In the latter case, the amount of stock transferred must be less than $18.5 \%$ of the target's outstanding common stock to avoid the requirement of shareholder approval under the New York Stock Exchange (NYSE) Rules. NYSE Company Manual § A15, at A283-84 (1978). The last method is often utilized by a friendly party at the request of the issuing corporation as a "lock-up" device in response to or in anticipation of an unsolicited takeover bid. A "lock-up" is an arrangement 
get's management becomes apprehensive about a loss of corporate control. Management attempts to use the standstill agreement both as a defensive tactic and as a shark repellent technique against takeovers, as well as a means of facilitating the raising of capital. It is generally in the best interests of both management and shareholders to maximize investor interest in the purchase of the corporation's stock, thereby attracting as much investment capital as possible. Management, however, may be concerned that if the corporation becomes too attractive, a single entity will acquire much of its stock and then be in a good position to launch a hostile takeover attempt. The option to negotiate a standstill agreement with a major shareholder eases this dilemma for management. Management is free to attempt aggressively to attract investment capital, and if a significant amount of the corporation's stock is bought by one entity instead of a widely scattered group of independent investors, management can seek to negotiate a standstill agreement.

A substantial shareholder will often have an incentive to enter into a standstill agreement as well. If such a shareholder intends an immediate takeover attempt, then it will not agree to the compromise of any standstill agreement. The large shareholder, however, may believe that the target corporation is financially sound and wish to invest in it without acquiring it outright. ${ }^{14}$ The shareholder would then be more likely to enter into a standstill agreement to ensure that management does not take costly and unnecessary defensive measures ${ }^{15}$ against it, and thereby decrease the value of its investment. The contracting shareholder also may be seeking, without management's destructive opposition, some measure of input into the corporation's decisionmaking. ${ }^{16}$ In addition, it may want to acquire twenty percent ownership of the corporation so that it can utilize the equity method of accounting in reporting its investment. ${ }^{17}$

Standstill agreements are designed to create a stable, certain, and coop-

or transaction by which a target corporation in a contested takeover gives one proposed acquirer a competitive advantage over other bidders or prospective bidders. Note, Lock-Up Options: Toward $A$ State Law Standard, 96 HARv. L. REv. 1068, 1068 (1983). Subsequently, the issuer and the friendly party often strike a deal (usually either a solicited tender offer, an amiable merger, a repurchase, or a standstill agreement).

14. See Bartlett \& Andrews, supra note 7, at 144.

15. See infra note 35 (examples of defensive measures management has at its disposal).

16. This is typically done through guaranteed board representation for the entire term of the standstill agreement. Spe supra note 10.

17. An investor directly or indirectly holding at least $20 \%$ of a corporation's voting stock is presumed to exercise significant control over the corporation's operating and financial policies, and must therefore use the equity method of accounting. AMERICAN INST. OF CERTIFIED PuB. Accountants, Professional Standards AC $\$ 5131.17$ (1974). Under this method, the investor gains certain financial reporting advantages. Id. at AC $\$$ 5131.19. The existence of a standstill agreement, however, depending upon its provisions, may rebut the presumption of control. Bialkin, The Use of Standstill Agreements in Corporate Transactions, 373 P.L.I. 91, 112-13 (1981). 
erative relationship between management and a major shareholder. ${ }^{18}$ The Martin Marietta-Allied agreement is currently the most advanced form of the standstill agreement. ${ }^{19}$ If left unchallenged, this form of standstill agreement will probably continue to be used in the future.

\section{Standstill Agreements as Illegal Shareholder Vote SELLING}

Standstill agreements are useful in regulating relations between management and a substantial shareholder. Their restrictive voting provisions, however, constitute a clear case of illicit vote selling. Vote selling is illegal under common law, against public policy, and violative of state statutes.

\section{A. Vote Selling Under Common Law}

According to common law, a shareholder cannot agree to vote in a predetermined way for private consideration..$^{20}$ The voting requirements of typical standstill agreements, however, achieve a result identical to vote selling. In exchange for personal consideration-a promise by manage-

18. This Note focuses on the most common function of the standstill agreement: governance of the relationship between a corporation and a large shareholder. Standstill agreements are also useful (1) in connection with the exchange of confidential information as a prelude to a subsequent corporate combination; (2) as part of a settlement of litigation between the signatories; and (3) to restrict a bidder if only the first part of a two-step merger transaction is completed. Bialkin, supra note 17 , at 93-94.

19. The salient provisions of the Martin Marietta-Allied Agreement, supra note 1, may be summarized as follows:

(1) Allied owns $39 \%$ of the outstanding common stock of Martin Marietta.

(2) Allied agrees not to acquire any more shares without the approval of the board of directors of Martin Marietta.

(3) Allied agrees not to sell, transfer, or otherwise dispose of its shares without the prior written consent of the board of directors of Martin Marietta.

(4) The shares owned by Allied are to be voted according to the wishes of Martin Marietta management.

(5) Allied agrees not to solicit proxies or become a "participant" in a "solicitation" in opposition to the recommendation of the Martin Marietta directors with respect to any matter.

(6) Martin Marietta agrees that it "will use its best efforts to the end that two persons designated by Allied and reasonably acceptable to Martin shall be elected to the Board of Directors of Martin."

(7) This agreement is to be operative for the next ten years.

Id. (emphasis added). Approximately 13 months after the agreement became operative, Martin Marietta repurchased all its shares owned by Allied. Marietta's Plan to Regain Independence From Allied Will Make Both Finns Money, Wall St. J., June 20, 1983, at 6, col. 3.

20. "A bargain to vote for corporate action in consideration of other private advantage than that which might accrue to the promisor from the benefit to the corporation from taking the action is invalid." 15 S. WILLISTON, LAw of CoNTRACTS $\$ 1736$, at 32 (3d ed. 1972). "A bargain by a large shareholder or group of shareholders for considerations, inuring to them personally, to procure the appointment of another as an officer of the corporation or to use their votes to keep the control in certain hands is int'alid." Id. at 30 (emphasis added).

"A bargain by an official or shareholder of a corporation for a consideration inuring to him personally to exercise or promise to exercise his powers in the management of the corporation in a particular way is illegal." Restatement of ConTracts $§ 569$, at 1074 (1932). 
ment to use its best efforts to elect the contracting shareholder's designees as directors, to allow the shareholder's purchase of stock up to a specified limit, or to grant certain securities registration rights to the shareholder - the contracting shareholder agrees to vote its stock as management dictates.

Some courts have refused to enforce voting agreements on the grounds that they constitute impermissible vote selling. ${ }^{21}$ Under this line of cases, standstill agreements constitute vote selling and therefore should be unenforceable.

The Delaware Chancery recently decided an important vote selling case: Schreiber v. Carney. ${ }^{22}$ The Schreiber court held that vote selling is illegal if it defrauds or disenfranchises the other shareholders. The voting restrictions in standstill agreements effectively disenfranchise shareholders not privy to the agreement. These shareholders' votes become meaningless in an election in which the outcome is virtually predetermined because a standstill agreement has contractually obligated a large block of stock (usually twenty to forty percent) to vote as management directs.

According to the Schreiber court's definition of fraud, ${ }^{23}$ standstill agreements defraud shareholders not privy to the agreement in two ways. First, they violate the shareholders' right to the best available managers. Stand-

21. See, e.g., Chew v. Inverness Mgt. Corp., 352 A.2d 426 (Del. Ch. 1976) (agreement to give proxy to vote stock in exchange for cash payment of $10 \notin$ per share and attractive option price held invalid); Hall v. Issacs, 37 Del. Ch. 530, 146 A.2d 602 (1958) (agreement to vote for certain persons as directors for period of ten years in exchange for favorable employment contract and loan of $\$ 30,000$ held to violate rule forbidding voting of purchased votes), aff d, 39 Del. Ch. 244, 163 A.2d 288 (1960); Macht v. Merchants Mortgage \& Credit Co., 22 Del. Ch. 74, 194 A. 19 (1937) (agreement to allow protective committee to vote shares in exchange for cash payments held against public policy and fraud on other shareholders); Stott v. Stott, 258 Mich. 547, 242 N.W. 747 (1932) (agreement by shareholder to vote in favor of corporate loan in exchange for cancellation of personal debt held void).

22. Schreiber v. Carney, 447 A.2d 17 (Del. Ch. 1982). The court held that an agreement whereby a 35\% shareholder withdrew its opposition to a proposed merger in exchange for a loan to fund the early exercise of its warrants was not void per se because it did not defraud or disenfranchise the other stockholders, but rather was for the purpose of furthering the interest of all the company's stockholders, and actually enfranchised the other stockholders by giving them a determinative vote in the proposed merger. Id. at 26.

The Schreiber court approved of the holdings in the prior Delaware vote selling cases, see cases cited supra note 21 , but suggested that to understand the reasons why vote selling is illegal one must consider the older cases cited in Merchants Mortgage, 22 Del. Ch. at 80,194 A. at 22 (these include Smith v. San Francisco \& N.P. Ry., 115 Cal. 584, 47 P. 582 (1897); Brady v. Bean, 221 Ill. App. 279 (1921); Dieckmann v. Robyn, 162 Mo. App. 67, 141 S.W. 717 (1911)). Schreiber, 447 A.2d at 24.

The Schreiber court saw essentially two principles. The first is that vote selling is illegal if it defrauds or disenfranchises the other shareholders. The second is that vote selling is illegal per se as a matter of public policy because it violates the duty of exercising independent and personal judgment in voting on corporate issues which each shareholder owes to the other shareholders and upon which every shareholder is entitled to rely. The Schreiber court maintained that this second principle is obsolete because it is impracticable and impossible to apply to modern corporations with many widely scattered stockholders, and asserted that courts have gradually abandoned it. Id. at 24-25.

23. The court defines a fraudulent purpose as "a deceit which operates prejudicially upon the property rights of another." Id. at 24 (emphasis added). 
still agreements tend to entrench current management and to lead to stagnation, thereby decreasing the value of the shareholders' investment in the corporation. Thus they "operate prejudicially upon" shareholders' property rights. Standstill agreements also tend to discourage unsolicited tender offers, in which shareholders are usually offered a significant premium for their stock. By depriving shareholders of this potential opportunity for profit, standstill agreements prejudice shareholders' property rights.

\section{B. The Public Policy Against Vote Selling}

Corporate scholars consider vote selling for private consideration to be against public policy. ${ }^{24}$ Ballantine states, "No doubt all agreements as to voting by a shareholder should be held contrary to public policy if the tendency of the bargain is to induce the voter to consider, in a decision affecting the rights of others, not the advantage of the corporation but the obtaining of advantages to himself . . ..25 A standstill agreement does not merely "induce the voter to consider" but contractually obligates him to vote with management, whether or not the voter believes that such action is in the best interests of the corporation. In return, the shareholder receives personal advantages: representation on the board of directors and securities registration rights. Hence, the restrictive voting provisions of typical standstill agreements violate public policy.

The contracting shareholder usually owns sufficient stock of the corporation to qualify as a controlling shareholder. ${ }^{26}$ It therefore owes certain fiduciary duties to the corporation's minority shareholders $\mathrm{s}^{27}$ which it cannot abdicate by entering into a standstill agreement with stringent voting requirements. The contracting shareholder violates its fiduciary duties by

24. "Thus, any agreement by a stockholder to sell his vote, or to vote in a certain way, for a consideration personal to himself is contrary to public policy and void." $5 \mathrm{~W}$. FLETCHER, Gyclopedia of the Law of Private Corporations $§ 2066$, at 291 (rev. perm. ed. 1976). "The stockholder cannot separate the voting power from his stock by selling his right to vote for a consideration personal to himself alone, any more than he could agree for the same consideration to cast the vote himself." Id. § 2065, at 282 (quoting Smith v. San Francisco \& N.P. Ry., 115 Cal. 584, 607, 47 P. 582, 590 (1897)).

25. H. Ballantine, Corporations 421 (1946).

26. See supra note 6. See, e.g., Essex Universal Corp. v. Yates, 305 F.2d 572, 579 (2d Cir. 1962) (ownership of $28.3 \%$ of voting stock in publicly held corporation is usually tantamount to majority control); Perlman v. Feldman, 219 F.2d 173, 174 n.1, 175 (2d Cir.) (33\% ownership creates fiduciary duty as controlling shareholder), cert. denied, 349 U.S. 952 (1955); D. VAGTS, Basic CoRPORATION LAw 454 (2d ed. 1979) (as little as 20\% ownership could constitute control "if the remainder of the stock is held by the scattered and semi-oblivious shareholders so typical of the large corporation"). In this context, "controlling shareholder" refers to the shareholder's ownership position for purposes of its fiduciary duties and does not connote actual domination of the corporation. Indeed, the very purpose of the typical standstill agreement is to prevent such domination.

27. See generally H. HeNn \& J. AlexANDER, supra note 8, § 240, at 654 (fiduciary duties can be imposed directly or indirectly on controlling shareholders); Finch \& Long, The Fiduciary Relation of the Dominant Shareholder to the Minority Shareholders, 9 Hastings L.J. 306 (1958) (discussing origin and nature of controlling shareholder's fiduciary duties). 
signing a standstill agreement which mandates that the shareholder vote as management dictates. The shareholder must acquiesce even if the corporation's management endorses oppressive or reckless conduct regarding the minority shareholders. It may be idealistic to suggest that a noncontrolling shareholder should consider solely what it believes to be the best interests of the corporation and not concentrate predominantly on its personal benefit when voting. ${ }^{28}$ Nevertheless, a controlling shareholder has a fiduciary duty to deal fairly with the minority shareholders. ${ }^{29}$ It cannot use its control of the corporation to oppress or defraud the minority shareholders. ${ }^{30}$

\section{Vote Selling Under State Statutes}

Some state statutes explicitly forbid shareholders from selling their votes or exchanging their proxies for money or "anything of value."'31

28. Fletcher, however, suggests just this by stating, "[i]n other words, stockholders have a duty to perform, that is, to use their voting power for the best interests of the corporation . . . but at all times must be free to cast their vote for what they deem the best interests of the corporation." W. FLETChER, supra note 24, § 2065, at 282.

29. See, e.g., Pepper v. Litton, 308 U.S. 295, 306 (1939) (controlling shareholder is fiduciary and its dealings with corporation are subjected to rigorous scrutiny); Zahn v. Transamerica Corp., 162 F.2d 36, 42 (3d Gir. 1947) (controlling shareholder has burden of proving good faith and inherent fairness of any transaction it enters into with corporation); Box v. Northrop Corp., 459 F. Supp. 540, 547 (S.D.N.Y. 1978) (majority shareholders stand as fiduciaries toward minority shareholders and are prohibited from pursuing any narrow self-interest in dealing with minority shareholders), aff $d, 598$ F.2d 609 (2d Cir. 1979).

30. H. HENN \& J. AlEXANDER, supra note 8, § 240

31. See Pa. Stat. AnN. tit. 15, § 1504.A (Purdon 1968); S.C. Code ANN. § 33-11-140(a) (Law. Co-op. 1982). N.Y. Bus. CoRP. LAW $\S 609$ (e) (McKinney 1963) provides: "A shareholder shall not sell his vote or issue a proxy to vote to any person for any sum of money or anything of value, except as authorized in this section and $\$ 620$." Section 620 authorizes an agreement between "two or more shareholders" to vote the shares held "by them" in a particular way. N.Y. Bus. CoRP. LAw \$ 620(a) (McKinney 1963). This exception only applies to an agreement between two shareholders; it does not apply to an agreement (such as a standstill agreement) between a shareholder and a nonshareholder, such as management. It should be noted that, even if management owns some shares, typical standstill agreements cover only the shares owned by the contracting shareholder and therefore do not satisfy the second requirement of the exception-that the agreement cover shares held by "them" (namely, both shareholders).

Section 620 and its counterpart in Delaware's corporate law, DeL. CoDE ANN. tit. $8, \S 218$ (c) (1953) - which also only applies to agreements by two or more shareholders covering shares held by both of them-are designed to legalize vote pooling agreements and voting trusts, whereby a group of shareholders agree to vote their shares in concerted action, or as a designated arbitrator or trustee demands. The consideration for each shareholder in such agreements is merely the other shareholder's promise to vote in a particular manner or as the same trustee dictates. This consideration is less pecuniary in nature and less definite than the consideration in a standstill agreement, and it accrues to a group of shareholders rather than to just one particular shareholder. Such agreements are therefore less like pure vote selling than is a typical standstill agreement.

Voting trusts and vote pooling agreements are basically devices created to solve the peculiar and troublesome collective-action problems of closely held corporations, such as achieving cooperation and avoiding voting deadlocks. There is a long line of New York case law that stands for the proposition that, "it is not against public policy or unlawful per se for stockholders to agree or combine for the election of directors or other officers, so as to secure or retain control of the corporation, particularly with regard to a close corporation as distinguished from a public-issue corporation." (emphasis ad- 
Long-term board representation under a standstill agreement is certainly something of value. ${ }^{32}$ Hence, standstill agreements violate these statutes.

\section{Standstill AgreEments AND Management's Fiduciary DUTY}

Anti-takeover measures have met a recent wave of scholarly criticism..$^{33}$ Gilson puts anti-takeover measures into two categories: (1) defensive tactics, ${ }^{34}$ which are used only after an offer is made or a likely offeror is identified, and the target's independence is in jeopardy; ${ }^{35}$ and (2) shark repellent techniques, ${ }^{36}$ which act as a deterrent by making the target a less desirable and more difficult acquisition, thereby convincing the potential

ded). W. Fletcher, supra note $24, \S 2064$, at 266; see In re I. Rokeach \& Sons, Inc., 142 N.Y.S.2d 460 (Sup. Ct. 1955); Cohen v. Wacht, 124 N.Y.S.2d 207 (Sup. Ct.), affd, 282 A.D. 1054, 126 N.Y.S.2d 910 (1953), appeal dentied, 283 A.D. 660, 127 N.Y.S.2d 820 (1954); Slonim v. Brodie, 109 N.Y.S.2d 440 (Sup. Ct. 1951), affd, 281 A.D. 861, 119 N.Y.S.2d 916 (1953); Tremsky v. Green, 106 N.Y.S.2d 572 (Sup. Ct. 1951); DeMarco v. Paramount Ice Corp., 30 Misc. 2d 158, 102 N.Y.S.2d 692 (Sup. Ct. 1950). The rationale of these cases cannot be assumed to justify vote selling in the context of publicly held corporations.

32. Long-term representation is valuable because it provides significant input in determining corporate policy, a role in policing management's conduct, access to inside information, and some financial remuneration.

33. See Gilson, supra note 4; Gilson, A Structural Approach to Corporations: The Case Against Defensize Tactics in Tender Offers, 33 Stan. L. Rev. 819 (1981).

34. There is a vast literature cataloguing the array of defensive tactics which has been developed. E.g., E. Aranow, H. Einhorn \& G. Berlstein, Developments in Tender Offers for Corporate Control. (1977); A. Fleischer, Tender Offers: Defenses, Responses, and Planning (1981); M. Lipton \& E. Steinberger, TAkeovers \& Freezeouts (1978); Reuben \& Elden, How to Be a Target Company, 23 N.Y.L. Sch. L. REv. 423 (1978); Wachtell, Special Tender Offer Litigation Tactics, 32 Bus. LAw. 1433 (1977).

35. Examples include: selling a block of securities to, granting options to purchase a block of securities or key assets to, or merging with, a "white knight"; making acquisitions that create antitrust and other regulatory problems; redeploying assets, such as the divestiture (sale or spin-off) of key assets or divisions perceived to be particularly desirable to the offeror; the target's placing a block of its authorized but unissued shares in "friendly hands"; partly or completely liquidating the company; the target's making a tender offer for its own stock; repurchasing stock from a large shareholder; commencing litigation alleging securities or other violations; making use of the pension fund's assets to finance various defensive tactics; and countering unwanted tender offers by making your own tender offer for the stock of would-be acquirors (the "pac-man" defense).

36. There is an extensive literature concerning shark repellent amendments.E.g., E. ARANOw, H. Einhorn \& G. BerLSTEIN, supra note 34, at 193-99; A. FleisCHER, supra note 34, at 6 to 24-11, 36-37; 1 M. Lipton \& E. STEINBERger, supra note $34, \S 6.23$, at 265-70; Black \& Smith, Antilakeoter Charter Provisions: Defending Self-Help for Takeoter Targets, 36 WASH. \& LEE L. Rev. 699 (1979); Hochman \& Folger, Deflecting Takeovers: Charter and Bj-law Techniques, 34 Bus. LAw. 537 (1979); Mullaney, Guarding Against Takeovers-Defensive Charter Provisions, 25 Bus. Law. 1441 (1970); Rose \& Collins, Porcupine Proposals, 12 Rev. Sec. Reg. 977 (1979); Smith, Fair Price and Redemption Rights: New Dimensions in Defense Charter Provisions, 4 DEL. J. Corp. L. 1 (1978); Yoran, Advance Defensive Tactics Against Takeover Bids, 21 AM. J. Comp. L. 531 (1973). 
offeror to refrain from beginning an attack. ${ }^{37}$ Standstill agreements are unusual in that they act as both a defensive tactic and a shark repellent. ${ }^{38}$

They are a defensive tactic with respect to the contracting shareholder because in response to a significant accumulation of its stock, management negotiates a standstill agreement, assuring that the shareholder will not buy additional shares, not solicit proxies, ${ }^{39}$ not vote contrary to management's wishes, and thus in effect not attempt to change control of the corporation. ${ }^{40}$

Standstill agreements are shark repellents with respect to all other potential offerors. By prohibiting the transfer of a large block of stock without management's prior written consent, they make it much more difficult for a hostile tender offer to succeed ${ }^{41}$ It is nearly impossible to tender hostilely for a majority of the corporation's stock because this large block of shares will never be tendered to any unfriendly party. In addition, by obligating a large block of stock to vote with management they make victory in a proxy fight much more difficult. ${ }^{42}$ An outsider seeking control of

37. Examples include: adopting charter and bylaw provisions designed to prevent changes in the board, such as staggering the board of directors, limiting the ability of shareholders to make nominations from the floor, limiting shareholder's rights to call special meetings and remove directors without cause, preventing packing of the board, limiting the ability of shareholders to take action by written consent, and allowing cumulative voting; adopting charter and bylaw provisions designed to protect minority shareholders in the event that a tender offeror is able to control the board, such as supermajority provisions requiring more than a majority of shareholders' votes to approve mergers or similar transactions with affiliates, fair price provisions, and compulsory redemption provisions; issuing "poison pill" preferred stock; authorizing the board, through a charter or bylaw amendment, to review any change in control in light of the effects on employees, the target's business, and the national economy; instituting extensive and expensive "golden parachute" contracts triggered by any change in control; and having loan agreements contain default provisions conditioned on changes in control.

38. Gilson, employing a structural approach to the modern corporation, makes a strong case against defensive tactics in one article, Gilson, supra note 33, and against shark repellents in a followup article, Gilson, supra note 4. Gilson defines this approach as "one that takes into account both the nonlegal constraints operating on the corporation and its constituents and the fact that a change in one part of the structure evokes a response from other parts that must be considered in evaluating the original change." Gilson, Sepking Competitive Bids Versus Pure Passizity in Tender Offer Defense, 35 STAN. L. REv. 51, 66 n.36 (1982). One would expect that this structural approach could be used to make an even stronger case against something that is both a defensive tactic and a shark repellent.

39. See, e.g., City Investing-NVF Agreement, supra note 6, at 1; Harnischfeger-Kobe Agreement, supra note 5, at 22; Martin Marietta-Allied Agreement, supra note 1, at 508; Norcen-Hanna Agrcement, supra note 3, at 11; Scott Paper-Brascan Agreement, supra note 3, at 8; Seagram-DuPont Agreement, supra note 3, at 536; Whittaker-Smith Agreement, supra note 3, at 10.

40. Some standstill agreements explicitly state that the signatory is to take no action to acquire or affect control of the corporation. See Albertson's Inc.-Theo Albrecht Stiftung-Theo Albrecht Agreement 5 (Feb. 15, 1980) (Exhibit 1 to Schedule 13D (amend. 4), filed with the SEC by Theo Albrecht Stiftung on Feb. 20, 1980); Scott Paper-Brascan Agreement, supra note 3, at 9.

41. The exact mechanism by which standstill agreements hinder hostile tender offers will vary depending upon whether they have a termination provision. If there is no termination provision, then there is an absolute prohibition against tendering to an unfriendly party. If there is a termination provision, then management's comprehensive right of first refusal operates to discourage hostile tender offers. See infra note 48.

42. Unlike many anti-takeover techniques, see supra notes 35,37 , which are primarily directed at either a tender offer or a proxy fight, a standstill agreement with restrictive voting provisions can be an equally effective deterrent to both a tender offer and a proxy fight. 
the proxy machine is at a nearly insurmountable disadvantage because this large block of shares cannot give its proxy to vote for any unfriendly party. Any corporation armed with such a standstill agreement therefore would be a difficult, risky, and arduous acquisition and hence an undesirable target. ${ }^{43}$

By entering into a standstill agreement with non-discretionary voting requirements, management violates its fiduciary duty of care and loyalty to its shareholders. ${ }^{44}$ It acts in its own ${ }^{45}$ rather than in the shareholders' best interest by attempting to secure control ${ }^{\mathbf{4}}$ of the corporation for periods as long as ten years. ${ }^{47}$ Management entrenches itself in three ways. First, management has an assured victory in any shareholder election because the standstill agreement has contractually obligated a significant percentage of the shares to vote with management. Second, the agreement greatly decreases the probability of any outsider succeeding in a proxy fight because a substantial block of voting stock cannot give its proxy to vote for anyone management opposes in any election of the board of directors. Third, the agreement discourages hostile tender offers by making a large block of stock unavailable to unfriendly buyers. ${ }^{48}$

43. To be an effective repellent, the existence of a standstill agreement must be public information available to all potential acquirors. Because the contracting shareholder almost always owns more than $5 \%$ of the corporation's outstanding common stock, see supra note 6 , it is subject to the Williams Act's public reporting requirements under $\S 13(d)(1)$ of the Securities Exchange Act of 1934 (the "1934 Act"), 15 U.S.C. $\$ 78 \mathrm{~m}$ (d)(1) (1982), and must file a Schedule 13D with the SEC. 17 C.F.R. $\S 240.13 \mathrm{~d}-1$ (1983). The existence of a standstill agreement must be disclosed under $\$ 13(d)(1)(E)$ of the 1934 Act, 15 U.S.C. $\$ 78(\mathrm{~m})(\mathrm{d})(1)(\mathrm{E})(1982)$.

44. This Note focuses on the breach of management's fiduciary duty to its stockholders. See generally W. Cary \& M. Eisenberg, Cases and Materials on Corporations 518-62 (5th ed. 1980) (broad survey of law regarding fiduciary duty of care); $i d$. at 562-712 (broad survey of law regarding fiduciary duty of loyalty). It should be noted that the restrictive voting terms of typical standstill agreements may also constitute a breach of the contracting shareholder's fiduciary duty to its own shareholders if it is a corporation. Once the contracting shareholder has relinquished its voting autonomy, it is powerless to oppose action by the corporation which is against the best interests of its own shareholders, and therefore becomes vulnerable to a derivative suit for breach of fiduciary duty. Bartlett \& Andrews, supra note 7, at 166.

45. Management's negotiation of a restrictive standstill agreement with a major shareholder could very well be characterized as an invalid contract under classic contract law. See $15 \mathrm{~S}$. WiLLISTON, supra note $20, \S 1737$, at 35 ("A bargain by officers of a corporation for personal advantage in return for entering into an agreement on behalf of the corporation with a third person is invalid.") (emphasis added).

46. Courts have found transactions primarily motivated by management's desire to retain control of the corporation to lack a proper corporate purpose and thus to constitute a breach of fiduciary duty. See, e.g., Chicago Stadium Corp. v. Scallen, 530 F.2d 204, 207 (8th Cir. 1976) (issuance of undervalued shares to president of corporation allegedly in satisfaction of debt, but actually intended to entrench management, violates fiduciary duty); Royal Indus. v. Monogram Indus. [1976-77 Transfer Binder] FED. SEC. L. REP. (CCH) T 95,863 (C.D. Cal. Nov. 29, 1976) (purchase of competitor undertaken solely to create antitrust obstacle to tender offer, and thereby perpetuate current management, violates § 14(e) of the Securities Exchange Act and should be enjoined); Condec Corp. v. Lukenheimer Co., 43 Del. Ch. 353, 363-65, 230 A.2d 769, 775-77 (1967) (directors' approval of stock issuance intended to perpetuate control by diluting offeror's interest violates fiduciary duty).

47. See supra note 5.

48. Because the contracting shareholder cannot sell or transfer any of its stock without manage- 
Standstill agreements hurt all shareholders not privy to the agreement. Senior management no longer has to worry about losing its positions, and is therefore more likely to become complacent. ${ }^{49}$ Such agreements restrict both the number and effectiveness of hostile takeover attempts, thereby impeding change in the senior management of the corporation and inhibiting the innovations and new ideas that often come with new personnel.

In an efficiently operating market, ${ }^{\text {s0 }}$ when management performs

ment's prior written consent, it cannot tender any of its shares to any party hostile to management. Making such a large block of stock unavailable to any unfriendly tender offeror makes it much more difficult to tender hostilely for a majority of the corporation's stock. Therefore, hostile tender offers are discouraged.

The discussion would end here if it were not for standstill agreements allowing for the termination of many of the restrictions in the agreement if an independent third party makes a bona fide hostile tender offer for a substantial amount of the corporation's stock. See, e.g., City Investing-NVF Agreement, supra note 6, at 3; Seagram-DuPont Agreement, supra note 3, at 533-34; Whittaker-Smith $\Lambda$ greement, supra note 3, at 8-9. It is important to note that many standstill agreements, however, contain no such termination provision. See Harnischfeger-Kobe Agreement, supra note 5, at 31 (termination only in case of friendly tender offer); Henkel Corporation-Clorox Company Agreement (Sept. 15, 1981) (Exhibit 5 to Schedule 13D (amend. 11), filed with the SEC by Henkel Corporation on Sept. 24, 1981) (no termination provision); Scott Paper-Brascan Agreement, supra note 3, at 17-18 (termination only in case of unopposed tender offer).

Even in standstill agreements in which a termination provision is triggered by a hostile tender offer, hostile tender offers are discouraged because all of these agreements provide management with a comprehensive right of first refusal. See City Investing-NVF Agreement, supra note 6, at 2-3; SeagramDuPont Agreement, supra note 3, at 542-46; Whittaker-Smith Agreement, supra note 3, at 12-26. The right of first refusal grants the corporation the option to purchase "or to cause a corporation, entity, person or group designated by the corporation to purchase," at the initial tender offer price, all shares subject to the standstill agreement before any such shares can be tendered. See Seagram-DuPont Agreement, supra note 3, at 543. This discourages hostile tender offers because after a corporation has incurred substantial costs (i.e., search costs involved in identifying a suitable target at a good price, see Easterbrook \& Fischel, Auctions and Sunk Costs in Tender Offers, 35 STAN. L. Rev. 1, 6 (1982); Easterbrook \& Fischel, The Proper Role of a Target's Management in Responding to a Tender Offer, 94 HARv. L. REv. 1161, 1178 (1981) [hereinafter cited as The Proper Role], as well as the costs involved in launching any tender offer, such as hiring a team of lawyers, investment bankers, and accountants, see $1 \mathrm{M}$. LIPTON \& E. STEINBERGER, supra note 34, §1.4, at 10-12) management can exercise its right of first refusal and designate a friendly third party, a "white knight," to purchase the shares at an identical price. This party, friendly to management as it is, will not tender its large block of stock to a hostile offeror and will vote against any hostile party in an election of the board of directors. Hence, the chance of success of a hostile tender offer is greatly decreased, and consequently hostile tender offers are discouraged.

$\Lambda$ small number of standstill agreements provide for the exercise of the right of first refusal at a price that may turn out to be less favorable than the initial tender offer price. See Whittaker-Smith Agreement, supra note 3, at 18-19 (providing for purchase at best price paid by any tender offeror if a bidding war ensues). To the extent that this makes finding a white knight more difficult (management always has the option of attempting to scare away the tender offeror offering the best price with a barrage of defensive law suits), the agreement will be a less effective but not ineffectual deterrent to hostile tender offers.

49. Easterbrook and Fischel use the term "agency costs" to describe the incentive to "siphon off profits, fritter away time, or otherwise further [its] own interest at the shareholders' expense" that the management of any corporation will have in the absence of control devices such as the fear of being fired. Easterbrook \& Fischel, Takeouer Bids, Defensize Tactics and Shareholders' Welfare, 36 Bus. LAw. 1733, 1735 (1981); see also Jensen \& Meckling, Theory of the Firm: Managerial Behavior, Ageng Costs and Oumership Structure, 3 J. FIN. EcoN. 305, 308 (1976) (introducing "agency costs" and defining them rigorousiy).

50. Evidence shows that securities markets in the United States are indeed inefficient. See J. Lorie \& M. Hamilton, The Stock Market: Theories and Evidence 70-97 (1973); Fama, 
poorly the value of the corporation's stock will be depressed ${ }^{51}$ and therefore the corporation will be an easier and more attractive takeover target. $^{52}$ This effectively ensures management's diligent performance and maintains a high stock price. The restrictive voting provisions of standstill agreements, however, greatly decrease the probability of success in unfriendly takeover attempts and therefore discourage hostile takeover attempts. Standstill agreements thereby minimize management's fear of hostile takeovers, and eliminate an effective mechanism for monitoring management's output ${ }^{53}$ and for ensuring a high market price for the corporation's stock. ${ }^{54}$ Hence, the shareholders are worse off.

Finally, standstill agreements effectively discourage unsolicited tender offers which are often made at a significant premium over the market price of the stock. ${ }^{\mathrm{st}}$ The shareholders' investment is worth less because

Efficient Capilal Markets: A Review of Theory and Empirical Work, 25 J. Fin. 383 (1970); Note, The Efficient Capital Market Hypothesis, Economic Theory and the Regulation of the Securities Industry, 29 StAN. L. Rev. 1031, 1034-57 (1977).

51. See Gilson, supra note 33, at 841 ("decrease in corporate profits, whether because of inefficient management or because efficient but self-dealing management has diverted too much income to itself, causes the price of the corporation's stock to decline to a level consistent with the corporation's reduced profitability"); Manne, Mergers and the Market for Corporate Control, 73 J. Pol. Econ. 110,112 (1965) ("As an existing company is poorly managed-in the sense of not making as great a return for the shareholders as would be accomplished under other feasible managements-the market price of the shares declines relative to the shares of other companies in the same industry or relative to the market as a whole.").

52. See Manne, supra note 51, at 113 ("The lower the stock price, relative to what it could be with more efficient management, the more attractive the take-over becomes to those who believe that they can manage the company more efficiently.").

53. See Easterbrook \& Fischel, The Proper Role, supra note 48, at 1173 ("Tender offers are a method of monitoring the work of management teams."); Gilson, supra note 33, at 848 ("all components of the structure of the modern corporation-market, judicial, and statutory-combine to establish a critical role for the tender offer: as the principal displacement mechanism by which the capital market may police the performance of management"); Dart Indus., Inc. v Conrad, 462 F. Supp. 1, 8 (S.D. Ind. 1978) ("A tender offer plays an important role in the health of the national economy in that it serves as a device which helps to maintain accountability of corporate management to its shareholders.").

54. One article observes, "The process of monitoring by outsiders poses a continuous threat of takeover if performance lags. Managers will attempt to reduce agency costs in order to reduce the chance of takeover, and the process of reducing agency costs leads to higher prices for shares." Easterbrook \& Fischel, The Proper Role, supra note 48, at 1174.

At least one court has recognized the power of tender offer threats in ensuring satisfactory managerial performance and thereby increasing the price of shares. Dart Indus., Inc. v. Conrad, 462 F. Supp. at 8-9.

The detrimental effects of standstill agreements can also be described in more economic terms: (1) there is a market for corporate control that operates as a "watchdog" on management, see Gilson, supra note 33, at 841; Manne, supra note 51, at 112; (2) standstill agreements constitute an artificial restraint on this market for control; (3) therefore standstill agreements decrease shareholder welfare, and thus harm allocative efficiency; (4) this is an anticompetitive result.

55. See Easterbrook \& Fischel, The Proper Role, supra note 48, at 1161 . While recent measurements of the size of tender offer premiums vary, the size of the premium is uniformly quite substantial. See, e.g., Bradley, Interfirn Tender Offers and the Market for Corporate Control, $53 \mathrm{~J}$. Bus. 345,345 (1980) (average premium of $49 \%$ in 161 offers studied); Chatlos, The SEC vis. Investors on Tender Offers, 56 HARv. Bus. REv., Sept.-Oct. 1978, at 6-7 (72\% average premium for cash tender offers made in 1977). 
such agreements foreclose an avenue for rapid and large increases in the price of their stock. Thus, the shareholders are harmed economically. ${ }^{56}$

Standstill agreements with restrictive voting provisions are employed as both a defensive tactic and a shark repellent. Such agreements are useful in both tender offers and proxy fights. Consequently, they are very effective in achieving the improper goal of managerial entrenchment and therefore require special scrutiny.

\section{Proposed Solutions}

Standstill agreements are objectionable because they contain severe voting restrictions. The Note suggests three possible solutions:

(1) make all the shares subject to a standstill agreement nonvoting;

(2) neutralize the impact of shares subject to a standstill agreement by requiring proportional voting;

(3) reverse the presumption of the business judgment rule if standstill agreements contain restrictive voting provisions.

\section{A. Proposal One}

Proposal One, making stock that is subject to a standstill agreement nonvoting, ${ }^{67}$ is a simple way of correcting the legal infirmities of a typical standstill agreement while still creating a stable and certain relationship between management and a major shareholder. ${ }^{58}$

Functionally, stock subject to a standstill agreement is like treasury stock $^{59}$-it is stock over which management has regained ultimate control. Treasury stock is nonvoting because otherwise management would be vot-

56. For a statistical study of the economic impact of current standstill agreements on shareholder welfare, see Dann \& DeAngelo, Standstill Agreements, Pritately Negotiated Stock Repurchases, and the Market for Corporate Control, 11 J. Fin. Econ. 275 (1983). Dann and DeAngelo's statistical significance tests indicate that standstill agreements, on average, reduce the wealth of nonparticipating shareholders. Id. at 290-91.

57. "Even after persons have become stockholders, they may surrender . . . their power to vote by agreement, by consenting to bylaws, or otherwise, provided the agreement does not violate any charter or statutory provision, and is not contrary to public policy." W. FLETCHER, supra note $24, \S 2029$, at 136-37.

58. The quorum requirements for shareholder meetings may have to be adapted to accommodate the fact that a large block of common stock is now temporarily nonvoting. This is easily accomplished by an amendment to the articles of incorporation or the bylaws.

59. Treasury stock may be defined as "shares which have been issued as fully paid and have thereafter been acquired by the corporation by purchase, donation or otherwise, but not retired or canceled or restored to the status of unissued shares." 11 W. FLETCHER, Cyclopedis of THE LAW of Private Corporations $\$ 5088$, at 38 (rev. perm. ed. 1971). For a compilation and analysis of statutory definitions of "treasury shares," see 1 MOdEL Bus. CoRp. ACT ANN. § 2(h), at 48-56 (2d ed. 1971). 
ing for itself. "It is not to be tolerated that a company should procure stock, in any shape, which its officers may wield to the purposes of an election; thus securing themselves against the possibility of removal." Stock subject to a standstill agreement, like treasury stock, should be nonvoting for exactly this reason. ${ }^{62}$

\section{B. Proposal Two}

Proposal Two requires that all shares subject to a standstill agreement be voted in the same proportion as the shares voted by all other holders.

This proposal would have the same practical effect as making the shares subject to a standstill agreement nonvoting. ${ }^{\text {"s }}$ This can be illustrated by a simple hypothetical. Suppose the XYZ corporation has 100 shares of common stock outstanding and 40 of those shares are subject to a standstill agreement. Assume that in an election among Directors $A, B$ and $C$, the 60 "free shares" (i.e., those not contractually obligated) vote as follows: 30 vote for $A, 20$ for $B$, and 10 for $C$. If the 40 shares subject to a standstill agreement must be voted as management directs, management could dictate the outcome of the election. ${ }^{64}$ If these shares were voted pro-

60. H. HENN \& J. AleXANDER, supra note 8, § 158, at 399; see also W. FLETCHER, supra note $24, \S 2041$, at 175-76 ("A corporation cannot, in any proper sense be a stockholder in itself, and shares of its own stock, therefore, held by a corporation, cannot be voted."); DEL. CODE ANN. tit. 8, § 160(c) (1953) (prohibiting corporation from voting shares of its own capital stock).

61. Ex parte Holmes, 5 Cow. 426, 435 (N.Y. Sup. Ct. 1826).

62. One possible ramification of making stock temporarily nonvoting should, however, be noted. The NYSE staff has indicated that it disfavors provisions of agreements which impede a shareholder's right to vote its securities of the target company. Bialkin, supra note 17, at 113-14. This is based on the NYSE's policy prohibiting the listing of non-voting common stock and "common stock (or other voting stock) where the voting rights of shareholders ... . would be restricted through the use of a voting trust, irrevocable proxy, or any similar arrangement to which the company or any of its officers or directors is a party, either directly or indirectly." NYSE COMPANY MANUAL $\S$ A15, at A-280 (1977).

Consequently, the NYSE may not favor making stock temporarily nonvoting. It should be noted, however, that this NYSE policy also disfavors the voting restrictions currently used in typical standstill agreements (a standstill agreement requiring the shareholder to vote as management dictates is a restriction of the voting rights of shareholders through an "arrangement to which the company or any of its officers or directors is a party, either directly or indirectly"). Hence, no new problem is created.

In light of this, it seems unlikely that the NYSE would use the sanction of delisting a corporation's stock just because a block of it has become temporarily nonvoting when it has made no public attempt to delist a corporation's stock for signing a standstill agreement with the severe voting restriction of mandating that the shareholder vote as management wishes. Bartlett \& Andrews, supra note 7, at 154 n.36. The NYSE does insist that parties file standstill agreements with it. Id. Besides, many corporations with large amounts of treasury stock are listed on the NYSE, and the NYSE does not resort to delisting merely because a corporation has increased its quantity of treasury stock; thus the possibility of delisting does not appear to be a very serious problem. Indeed, the NYSE would have difficulty enforcing any new policy of this nature without having first submitted it to the SEC for approval.

63. Requiring proportional voting might entail slightly greater transaction costs than simply making the shares nonvoting (i.e. the contracting shareholder would have to make the effort to attend shareholder meetings or take the time to register its proportional vote by proxy).

64. Either Director $A, B$, or $C$ could win the election if management dictates that all 40 shares subject to the standstill agreement be voted for that particular director. 
portionally, however, $A$ would receive 50 votes, $B$ would receive $331 \frac{1}{3}$, and $C$ would receive $16^{2} / 3$. In percentage terms, these election results are the same as if the 40 standstill shares were nonvoting (i.e., $A$ has $50 \%$ of the vote, $B$ has $331 \frac{13 \%}{\%}$ of the vote, and $C$ has $162 / 3 \%$ of the vote). ${ }^{68}$

Making stock that is subject to a standstill agreement nonvoting or requiring proportional voting would restore the democratic nature of the corporate election. No longer could management dictate the outcome of an election solely by using a standstill agreement to force a large block of stock to vote for it. Making that block nonvoting would decrease the size of the total voting population, but the size of the freely voting population would remain unchanged. ${ }^{68}$ This large and diverse group of shareholders would now govern the outcome of the election.

Proposal One and Proposal Two would also eliminate the effectiveness of the standstill agreement as a shark repellent because management would no longer be protected from either a hostile tender offer or a proxy fight. In terms of the previous hypothetical, to successfully take over the $X Y Z$ corporation if management held a standstill agreement mandating that 40 of the corporation's 100 outstanding shares be voted as current management dictates, an offeror unfriendly to management would have to tender for 51 out of 60 shares or solicit 51 out of 60 proxies, both very difficult tasks. ${ }^{67}$ Under Proposal One and Proposal Two, however, an offeror would have to tender for only over $50 \%$ of the freely voting shares or solicit over $50 \%$ of these shares' proxies (i.e., 31 out of 60 ) to gain control of the corporation. ${ }^{68}$ These tasks would require the same percentage of favorable responses from noncommitted shareholders to succeed in a takeover attempt as would be required to succeed in a takeover attempt of the $X Y Z$ corporation with no standstill agreement. ${ }^{68}$ Finally, Proposal One and Proposal Two would eliminate the vote selling criticism since under them management would have no effective voting power. ${ }^{70}$

It is important to recognize that these proposals ${ }^{71}$ would eliminate the

65. Perhaps shares required to be voted proportionally would be looked on more favorably by the NYSE than shares which are temporarily nonvoting. See supra note 62.

66. In terms of the hypothetical, the total voting population would be reduced from 100 to 60 ; however, the free voting population would remain at 60 .

67. Both tasks would require $85 \%(51 / 60)$ of the responses of previously uncommitted shareholders to be in favor of the offeror.

68. These tasks would require approximately $51 \%(31 / 60)$ of the responses of previously uncommitted shareholders to be in favor of the offeror.

69. Thirty-one out of 60 is approximately equal to 51 out of $100(51 \%)$.

70. It should be noted that under Proposal One and Proposal Two, if management owns some stock, then the voting power of that stock would be increased by stripping some outstanding shares of their votes. This is not a very important consideration because senior management rarely owns a significant percentage of the outstanding common stock of a major public corporation. Also, Proposal One and Proposal Two would increase proportionately the voting power of all shares not subject to the standstill agreement.

71. Another possible proposal is to allow shares subject to a standstill agreement to be freely voted 
undesirable characteristics of standstill agreements but would still permit the use of standstill agreements in certain situations in which they benefit all shareholders. Under Proposal One and Proposal Two, management could no longer use a standstill agreement as a shark repellent measure to inhibit all future takeover attempts, ${ }^{72}$ but management could still use one to negotiate with a large shareholder to ensure that it will not attempt a takeover for the term of the agreement.

Such a compromise would increase the shareholders' well-being. The standstill agreement is a freely negotiated and carefully crafted settlement between parties of approximately equal bargaining strength. It is thus less damaging and less costly to the corporation and its shareholders than other defensive techniques that management might employ: selling off key assets or divisions to make the corporation less desirable to an offeror; liquidating the corporation; selling shares to a friendly party at an inadequate price to dilute the offeror's holdings, ${ }^{73}$ repurchasing stock from a large shareholder, often at a significant premium; commencing lengthy litigation often employing expensive takeover lawyers; manufacturing antitrust problems by acquiring one of the offeror's competitors, regardless of whether the acquisition fits with the corporation's current business plans or represents the most efficient use of the newly acquired asset; or making its own tender offer for the stock of the would-be acquiror. Enabling standstill agreements to occupy such a middle-ground position would be beneficial and desirable for shareholders.

\section{Proposal Three}

Management may defend a standstill agreement under the business judgment rule. Under this rule, courts must defer to any actions of directors "taken in good faith and in the exercise of honest judgment in the lawful and legitimate furtherance of corporate purposes." 74 Directors are

by the contracting shareholder. Management, however, would never agree to this. Such a proposal would give the contracting shareholder working control of the corporation and would defeat the main purpose of management's entering into a standstill agreement in the first place: fear of losing control of its corporation.

Proposal One and Proposal Two would leave control of the corporation unchanged. Although management would prefer to have standstill agreements in which it can dictate how the shares are voted, it is not unreasonable to assume that it would agree to Proposal One and Proposal Two.

72. Consequently, management would not be entrenched for the term of the standstill agreement and shareholder welfare would be improved. See supra pp. 1103-06.

73. This has the detrimental side effect of diluting all the shareholders' holdings and decreasing the value of their investment. See R. Brealy \& S. Meyers, Principles of Corporate Finance 296 (1981) (underpricing in offering of securities enables investor who buys issue to get bargain at expense of firm's existing stockholders).

74. Auerbach v. Bennett, 47 N.Y.2d 619, 629, 393 N.E.2d 994, 1000, 419 N.Y.S.2d 920, 926 (1979). 
presumed to have acted properly and in good faith, and plaintiff bears the burden of proving that the board of directors "had an interest in the transaction, or acted in bad faith or for some improper purpose."'75

The Note's third proposal suggests reversing this presumption ${ }^{76}$ if management enters into a standstill agreement with restrictive voting provisions. Management would be presumed ${ }^{77}$ to have acted for its own benefit (i.e., to entrench itself in control of the corporation for a long period of time). It would bear the burden of proving that the transaction did not violate its fiduciary duties.

Although this solution would not be as effective as the first two in precluding abusive standstill agreements, it would discourage the inclusion of offensive voting restrictions in standstill agreements. ${ }^{78}$ Because of the great

75. Treadway Cos. v. Care Corp., 638 F.2d 357, 383 (2d Cir. 1980).

76. The Delaware Supreme Court has taken steps towards reversing the presumption of the business judgment rule in the context of dismissal of derivative suits by special litigation committees. See Zapata Corp. v. Maldonado, 430 A.2d 779 (Del. 1981). In Zapata, the court placed the burden of proving the independence and good faith of the directors on a special litigation committee upon the corporation. Id. at 788. Under the standard version of the business judgment rule, such independence and good faith would be presumed, and the burden of showing bad faith would be on the plaintiff. See also Cheff v. Mathes, 41 Del. Ch. 494, 504-05, 199 A.2d. 548, 554 (1964) (placing burden on directors to prove good faith in authorizing repurchase, with corporate funds, of large block of corporation's stock).

77. To rebut the presumption, management would have to prove that the primary purpose of the standstill agreement was not self-serving entrenchment, and that the standstill agreement benefited the corporation as a whole and was fair to all the stockholders. It is more reasonable to place the burden on management to prove that the primary or sole purpose of a standstill agreement was not retention of control than to place the burden on the plaintiff to prove that retention of control was the sole or primary motivation of management. Current case law, however, places the burden on the plaintiff to show that management's sole or primary purpose was retention of control. See Johnson v. Trueblood, 629 F.2d 287, 293 (3d Cir.) (plaintiff "must make a showing that the sole or primary motive of the defendant was to retain control .... [T] transaction in question had a valid corporate business purpose."), vacated on other grounds, 629 F.2d 302 (3d Cir. 1980) (per curiam), cert. denied, 450 U.S. 999 (1981).

The current standard, as enunciated in Johnson, places a nearly impossible burden on plaintiffs and allows management to escape liability merely upon a showing that some other plausible motivation besides entrenchment exists. Management is the party with the conflict of interest as well as ready access to more information and evidence. It should bear the burden of proof. Putting the burden of proving a fact on the party who presumably has peculiar means of knowledge of the fact is recognized as a proper evidentiary standard. See $9 \mathrm{~J}$. Wigmore, Evidence in Trials at Common LAW $\S$ 2486 , at 290 (rev. ed. 1981).

If management enters into a standstill agreement with restrictive voting provisions instead of a standstill agreement with the voting provisions outlined in Proposal One and Proposal Two (which have substantial benefits, no costs, and still accomplish the aims of current standstill agreements), then the presumption that management acted for its own benefit would be very difficult to rebut. If, however, a standstill agreement were used (1) in connection with the exchange of technical information, trade secrets, or other business advantages between the signatories as prelude to subsequent corporate combination; (2) as part of a settlement of litigation between the signatories; or (3) in connection with a first-step tender or exchange offer pursuant to a merger agreement, see supra note 18, then the presumption would be much easier to rebut.

78. It is possible that a target could circumvent legal restrictions on standstill agreements by entering into agreements less formal than standstill agreements. The situation in which a standstill agreement is useful, however, calls for a very formal, binding, and judicially enforceable contract. Absolute certainty that its corporation is not the target of a takeover attempt often is the very reason management seeks to negotiate a standstill agreement. It is unlikely that management would be satis- 
protection the business judgment rule affords management in the use of various techniques to oppose a proposed hostile takeover, suits by shareholders to recover the substantial premium lost because a takeover attempt is thwarted are almost always unsuccessful. ${ }^{79}$ The strong presumption of the business judgment rule makes it difficult to win any shareholder suit challenging management's actions to prevent takeovers. Reversing the presumption and placing the burden of proof on management if the corporation enters into a standstill agreement with restrictive voting provisions would increase the chance of success of a shareholder suit. This would lead to more suits against managers who negotiate standstill agreements with non-discretionary voting requirements, ${ }^{80}$ and would result in closer monitoring of the use of standstill agreements.

Proposal Three would not completely prohibit management from entering into a standstill agreement with restrictive voting provisions; if management did, however, it would have the burden of proving that the agreement had beneficial effects accruing to all the shareholders that outweighed the costs and potential for abuse. Shifting the presumption of the business judgment rule would provide management with the proper incentive only to enter into standstill agreements that benefit all the shareholders or face the threat of shareholder suits more likely to succeed.

\section{Conclusion}

Standstill agreements arise predominantly in the context of mergers and acquisitions. $^{81}$ For example, a standstill agreement between Seagram Company and Dupont Company ${ }^{82}$ was executed in connection with one of

fied with a less formal, less certain agreement. The large shareholder who may be uninterested in gaining control of the corporation may fear that management will take costly, frustrating, and unnecessary defensive measures against it, thereby reducing the value of its investment. Its motivation for entering into a standstill agreement is certain assurance from management that this will not happen. It too would be unlikely to enter into an informal agreement which does not maximize certainty.

In fact, because certain enforceability and binding commitment is so important to both parties, standstill agreements usually contain very stringent damages provisions in the event of a breach by either party. Most standstill agreements stipulate that irreparable harm shall occur upon breach, and that the parties are entitled to injunctive relief and may obtain specific performance of the agreement. See, e.g., City Investing-NVF Agreement, supra note 6, at 4-5; Harnischfeger-Kobe Agreement, supra note 5, at 44-45; Martin Marietta-Allied Agreement, supra note 1, at 519; Norcen-Hanna Agreement, supra note 3, at 26; Scott Paper-Brascan Agreement, supra note 3, at 19; SeagramDuPont Agreement, supra note 3, at 547; Whittaker-Smith Agreement, supra note 3, at 29.

79. See, e.g., Panter v. Marshall Field \& Co., 646 F.2d 271 (7th Cir.), cert. denied, 454 U.S. 1092 (1981); Lewis v. McGraw, 619 F.2d 192 (2d Cir.) (per curiam), cert. denied, 449 U.S. 951 (1980); Berman v. Gerber Products Co., 454 F. Supp. 1310 (W.D. Mich. 1978).

80. In one such suit, a shareholder challenged the Martin Marietta-Allied Agreement, supra note 1, claiming that Martin Marietta's directors used it to perpetuate their control. Martin Marietta Is Sued By Investor to Nullify Pact With Allied Corp., Wall St. J., Oct. 14, 1982, at 7, col. 3.

81. See supra p. 1093 (Martin Marietta-Allied Agreement).

82. Seagram-DuPont Agreement, supra note 3. 
the largest corporate takeovers, the Dupont-Conoco merger. ${ }^{83}$ Given the great increase in takeover activity in recent years, ${ }^{84}$ it is logical to assume that standstill agreements will be increasingly popular in the future. Therefore this is an appropriate time to address this problem.

No court has yet considered any objections to the use of a standstill agreement to govern and define the relationship between a corporation and a major shareholder, ${ }^{85}$ and legislatures have not yet developed a way to respond to them. This Note outlines an appropriate response.

Changing the voting provisions of typical standstill agreements as this Note proposes would still permit such agreements to serve their valuable functions but would prevent them from insulating current management from all future takeover attempts. Prohibiting management from dictating how shares subject to a standstill agreement are voted is a simple yet effective way of correcting the infirmities of current standstill agreements. Standstill agreements could no longer be used as a shark repellent in the context of both a tender offer and a proxy fight. However, they could still be useful as a less costly and less damaging defensive tool to negotiate with a major shareholder. They would enable the corporation to attempt aggressively to attract investment capital without risking a loss of control and would allow the contracting shareholder to acquire a substantial block of stock without destructive opposition from management. ${ }^{86}$

-Steven A. Baronoff

83. See Is Any Company Safe From Takeover?, Fortune, Apr. 12, 1984, at 19.

84. See After Wave of Mergers, Analysts Debate Pluses, N.Y. Times, May 31, 1982, at D1, col. 1 ("The latest surge in merger activity has only two quantitative equals in United States industrial history ....").

85. In contexts other than governing the relationship between a corporation and a substantial shareholder, courts have examined standstill agreements. See Crouse-Hinds Co. v. Internorth Inc., 634 F.2d 690, 696, 702-04 (2d Cir. 1980) (approving standstill agreement signed as an incident to first-step tender offer or exchange offer pursuant to a merger agreement); General Portland Inc. v. LaFarge Coppee S.A., [1982-83 Transfer Binder] FED. SEC. L. REP. (CCH) II 99,148, at 95,542-43 (N.D. Tex. Aug. 28, 1981) (enforcing standstill agreement signed in connection with exchange of confidential information as prelude to possible business combination).

86. In addition to the beneficial functions mentioned in this paragraph, standstill agreements are useful for the same reason that any legally binding contractual commitment is useful. They bring order and reliability to a relationship that was previously ambiguous and uncertain. See generally F. Kessler \& G. Gilmore, Contracts 1 (2d ed. 1970) ("Indeed, contract is a principle of order of such universal usefulness that even a socialist economy cannot dispense with it.").

Common law courts, for reasons of public policy, have never hesitated to deny enforcement to contracts with illegal objectives. See generally 1 S. WILLISTON, LAW OF ConTRACTS $\S 19$, at 35 (3d ed. 1957) (illegality with respect to object for which contract is formed or consideration for which promise is given will generally preclude enforcement of the contract). This Note argues that standstill agreements with restrictive voting provisions serve illegal purposes, namely vote selling and breach of fiduciary duty. Consequently, if the Note's proposals are not adopted, such standstill agreements may be unenforceable contracts. 